\title{
Work-life-health challenges of women in project management in nongovernmental organisations in Serbia
}

\author{
Radmila Miković \\ PhD Candidate in Management \\ Faculty of Organizational Sciences, \\ University in Belgrade \\ Belgrade, Serbia \\ radmila.mikovic@gmail.com
}

\author{
Sofija Cerović \\ $P h D$ in Psychology \\ Faculty of Philosophy, \\ University in Belgrade, \\ Belgrade, Serbia \\ sofija.cerovic@yahoo.com
}

\author{
Danijela Toljaga-Nikolić \\ Department for Management and \\ Spezialized Management Disciplines \\ Faculty of Organizational Sciences, \\ University in Belgrade \\ Belgrade, Serbia \\ danijela.toljaga.nikolic@fon.bg.ac.rs
}

\begin{abstract}
This research aimed to explore the profile of women who work in project management in nongovernmental organisations (NGOs) in Serbia, their working conditions and their satisfaction with the job. The results show that women who work as project managers or project team members in NGOs in Serbia are highly educated, they work more than it is prescribed by the contract and, in half of the cases, it is about temporary employment agreement. They are satisfied with the position in NGOs, interpersonal relations and employers' care about employees. They also have the possibility of additional education. On the other hand, they are dissatisfied with the salary and standard of living, and they encounter stress-related problems.
\end{abstract}

Keywords-NGO, women, project, project management, work, education, life, health, Serbia.

\section{INTRODUCTION}

NGO sector is the eighth largest economy in the world, worth more than $\$ 1$ trillion a year globally, with over 19 million paid workers, countless volunteers and the authority to manage projects worth billions of US dollars annually [1]. As an active participant of international development, NGO sector has been considered as a data-, information-, and knowledge-intensive industry, which some have characterised as "development 2.0." [2]. In the last few decades, the focus on nongovernmental organisations and civil society has increased. There are two factors that led to perceiving NGOs as important actors in political, economic and social development $[3 ; 4]$. On the one hand, it became obvious that the influence of the state on development is limited [5], while, on the other hand, it was recognised that NGOs and civil society have the potential to participate in political and economic changes [6].

NGOs have been the subject of numerous academic studies over the past 30 years. There is now a substantial literature that discusses their actual and potential role in development, democratisation, and poverty alleviation [7].
There are many factors that determine the development of NGOs and civil society, and they are all related to the political, economic and social situation in the state [8]. The challenges that NGOs face are most often caused by public legitimacy and accountability, relations with the government, as well as by business and international relations [8]. Duration of NGOs operating in a country determines the amount of public support they receive and the understanding of their activities. On the other hand, the government establishes the legal and political context within which NGOs operate [9, 10]. Additionally, many NGOs have realised the role of the business sector in economic development, as well as of the international actors as sources of ideas, financial resources, and political legitimacy [8]. Having this in mind, it is important to observe and analyse all these factors to understand the development of NGO sector in different countries.

\section{THEORETICAL BACKGROUND - NGOS AS A WORKING ENVIRONMENT}

\section{A. NGOs in Serbia}

After the civil society had played an important role at the end of communist regimes during the 1980s, it was perceived as an actor that can facilitate the implementation of democracy in Eastern Europe [11]. In response to the legacy of socialism, civil society was conceptualised as a political and social space in which citizens could articulate their interests [12]. The legalisation of pluralism and permission of free association of citizens at the beginning of the 1990s led to an increased number of NGOs in Serbia [13]. During that period, NGOs in Serbia operated in unfavourable conditions due to war, sanctions, international isolation and increased unemployment rate.

In the 2000s, number of NGOs continued to increase. Based on the research conducted in 2009 [14], the main areas of NGOs activity in Serbia were culture, education and ecology, humanitarian work, youth and economy and human rights. The main beneficiaries of NGOs in Serbia were citizens and 
particularly youth, women and children. In 2009, most NGOs in Serbia were renting their offices, while the rest had their own space, did not have the office or use the office free of charge. Regarding the working equipment, 4/5 of NGOs in Serbia had at least one computer, most of them also had a modem, fax, scanner, camera and photocopy machine, while only $1 / 5$ had a company car. Almost all of them had access to Internet. The majority of NGOs in Serbia offered to their employees the opportunity for education, which was evaluated as an aspect of employees' satisfaction.

Studies suggest that the public perception of NGOs in Serbia in 2009 was not ideal [15]. 20\% of respondents did not know anything about NGOs. On the other hand, the associations that respondents had with NGOs were slightly more positive than negative; namely, $34 \%$ of respondents had a positive or neutral attitude towards NGOs, while $29 \%$ of them had negative attitude. In comparison to the study conducted in 2006 when the negative perception of NGOs in Serbia was dominant [16], these results suggested that there was a subtle shift in public perception of NGOs in Serbia.

In the first decade of the $21^{\text {st }}$ century, more than half of the NGOs were not satisfied with the relationship between the state and NGOs, reporting that the state underestimated the importance of this sector [14]. Yet, in 2009 the Law on NGOs was adopted and the office for collaboration with the government was formally established by a government decree in April 2010, both illustrating the increased influence of the sector and improved communication with the government.

Based on the research in 2011 [17], there were 4200 people with full-time employment in civil society organisations, 4500 people had part-time employment, while more than 150000 were volunteers. The main scope of activity in 2011 included social services, culture, media, recreation and environment.

In the past couple of years, NGOs became very engaged with Serbia's EU accession process criticising the reforms and complaining about physical assaults on their activists and verbal abuse in progovernment media [18].

\section{B. Working at NGOs}

Parallel with the state and private sector, NGOs became an employer for many professionals [19]. In spite of that, there are not numerous studies that explore job opportunities and conditions that are offered to employees by NGOs [7].

The characteristics of work and working conditions in NGOs are determined by the way NGOs function. An NGO establishes itself when there emerges a project in line with its mission. After that, the NGO seeks funds from donors that are assigned for that particular project. Functioning under project based structures [20] and the dynamics of pursuing another project after the previous is finished determines several aspects of work in NGOs [21]. First, unstable project financing of NGO work influences permanent lack of resources such as talented workforce, expert-based partnerships, IT and digital equipment, etc. which all have been identified as the most serious obstacle for NGOs to acquire the missing knowledge and skills [22]. Second, most NGO jobs are temporary since they depend on projects that are limited in time [7]. This has an impact both in the sense of insecurity because employees are not sure whether their contract will be extended, and on career development, because there is little space for promotion [7]. Third, financial rewarding of employees can be a contentious issue, since the money comes through public funds that are meant to be allocated for the particular project [21]. Finally, as in the case of most jobs that can be classified as helping professions, working in NGOs can be related to stress and burnout [21] that may cause eventual decision of professionals to change job after they tried their best to overcome difficulties that are to make the situation better and rewarding appropriate [23].

When it comes to reasons why people start working at NGOs, the main one is the satisfaction of serving the community in concrete ways and the experience of working with like-minded people [7].

\section{Women in $\mathrm{NGOs}$}

Scholars have concluded that women are numerous among professionals employed by NGOs [7; 24]. In spite of that, to authors' best knowledge, only two studies investigated the profile and the status of women in the NGO sector, as well as their job satisfaction. A study conducted in Jordan has demonstrated that majority of the employees in NGOs in Jordan are highly educated women [25]. They are seeking career challenges, and opportunities and the main reason for working in NGOs are new experiences, projects and hands-on learning. They began working in an NGO because of the career challenges and opportunities that NGOs offer, such as new experiences, projects and hands-on learning. The study also revealed that most of respondents were very satisfied with their jobs in NGOs. Additionally, another research found that most of employees in NGOs in Egypt are women and that they work at top management positions. The characteristics of their work are long working hours, working weekends and frequent business trips [7].

The aim of this study is to explore the profile of women working in project management in NGOs in Serbia, working conditions in NGOs, as well as employees' satisfaction with various aspects of their jobs.

\section{RESEARCH METHOD}

\section{A. Sample}

The sample consists of 180 women who work as project managers or project team members in NGOs in the Republic of Serbia, predominately in organizations 
that operate in the area of democracy and civil education, active participation of citizens in social changes, development of nonprofit sector, strengthening the position of vulnerable social groups such as women, youth, Roma, elderly, etc.

\section{B. Instruments}

To collect data about women employed in NGOs, a questionnaire consisting of 32 questions was made. The questions referred to educational level, working conditions (namely working hours and schedule, type of contract, salary, and possibility for education), health issues, as well as to employees' satisfaction with different aspects of work in the NGO (interpersonal relations, employer's care about employees). Internal consistency of the questionnaire was satisfactory $($ Crombah Alpha $=0.78)$.

\section{Procedure}

The questionnaire was sent directly to NGOs via the web link.

\section{RESULTS}

The results show that $88.1 \%$ of respondents hold at least a Bachelor degree; out of them $44.2 \%$ hold a Master degree and $1.7 \%$ has a PhD.

$53 \%$ of women in NGOs in Serbia have employment contracts, while the rest of them have some other kind of employment agreement, such as temporary employment agreement, volunteering agreement, etc.

Regarding working hours, $53.6 \%$ of respondents have flexible working hours. Work agreement prescribes on average, 7.53 working hours per day, but, in reality, they work on average 9.24 hours per day. When asked whether they are satisfied with the number of working hours, $56.4 \%$ responded positively. Similarly, $74 \%$ responded to be satisfied with their working schedule.

Majority of respondents assess their current position as intermediate $(51.4 \%)$ or high $(27.6 \%)$ in organisational hierarchy, while $14.4 \%$ is on a lowlevel position and $6.6 \%$ is freelance. Additionally, $74 \%$ of women say to be satisfied with their current position in the organisation. The analysis shows that there is a relationship between satisfaction with working hours and the position in the organisation $(\chi 2=8.535 \mathrm{p} 0=0.036)$. Namely, women who have high position in organisation and freelancers tend to be less satisfied with working hours.

Women in NGOs assess their salary as sufficient for survival, indicating that their earnings cannot provide good standard of living. $34 \%$ of women state to be the only source of family finances, while $42 \%$ of women share this responsibility with the partner.

Results show that NGOs provide the opportunity for education and development of employees. Specifically, $25.7 \%$ women report that they have some education monthly, $34.1 \%$ quarterly, $19.6 \%$ semi- annually and $13.4 \%$ annually. Only $3.9 \%$ of women do not have the opportunity for education. The most frequent types of education are seminars (90.6\%) and conferences $(82.3 \%)$.

$77.3 \%$ of women in NGOs report one or more health issues. The more frequent ones are those related to stress $(28.1 \%)$, followed by spine problems $(23.5 \%)$ and problems with eyes $(15.7 \%)$. Additional analysis show that the number of working hours has the effect on problems with eyes $(\mathrm{B}=0.17, \chi 2=5.091, \mathrm{p}=0.024)$, problems with spine $(\mathrm{B}=0.14, \chi 2=3.880, \mathrm{p}=0.049)$ and on stress-related problems $(B=0.18, \quad \chi 2=7.005$, $\mathrm{p}=0.008)$. Also, there is a relationship between the satisfaction with working hours and existence of health issues among women in NGOs $(\chi 2=10.976$, $\mathrm{p}=0.001)$. Less satisfied with working hours are women that have health problems, specifically, problems with eyes $(\chi 2=6.650, \mathrm{p}=0.010)$, problems with spine $(\chi 2=12.903, \mathrm{p}=0.000)$ and stress-related problems $(\chi 2=23.819, \mathrm{p}=0.000)$. Nevertheless, $54.7 \%$ of respondents manage to attain work-life balance.

Regarding employees' satisfaction with different aspects of work in NGOs, $79.6 \%$ of women are satisfied with interpersonal relations, $75.7 \%$ are satisfied with working conditions, while $79 \%$ are pleased with employers' care about employees. Additionally, when asked about the reasons for their satisfaction with work in NGOs, $30 \%$ of women respond passion for work, $17.9 \%$ good interpersonal relations, $16.6 \%$ creativity, $15.5 \%$ customer satisfaction and $12.5 \%$ working conditions. On the other hand, reasons for dissatisfaction are low salary $(31.5 \%)$, stress-related problems $(13.8 \%)$, career stagnation $(9.4 \%)$, job insecurity $(8.6 \%)$, etc.

\section{DISCUSSION}

The aim of this study was to explore the profile of women working in project management in NGOs in Serbia, their working conditions in NGOs, as well as their satisfaction with various aspects of their jobs.

The results indicate that women in NGOs in Serbia are predominately well educated. More specifically, these results confirm the existing research that middleclass women became interested in employment within NGOs [24].

Regarding the working conditions, the results from Serbia are in line with the research from Egypt, which showed that jobs in the NGO sector are insecure [7]. Half of women in NGOs in Serbia work on some temporary agreement basis. They work more hours than defined by the contract, which is similar to the situation in Egypt [7]. This has an effect on health issues women in NGOs in Serbia face. Namely, working hours and (dis)satisfaction with working hours predict problems with eyes, spine and stress. Despite that, most women are satisfied with their working schedule, probably because they are not fully aware of the effect of working hours and schedule on their health. 
Women who work as project managers or project team members in NGOs in Serbia are satisfied with their current position. More specifically, half of them are at the intermediate or high position, which is consistent with the findings from Egypt [7]. On the other hand, the finding that women at high position are less satisfied with working hours implies that high position means longer working hours. NGOs in Serbia provide opportunities for education and development of employees. The most common types of education are seminars and conferences. Additionally, the majority of women assess the interpersonal relations in organisations as good, as well as the employer's care about them. Women in Serbia are satisfied with their job in NGOs because it fulfils their passion for work, they have good relations with colleagues and because it gives them space to be creative.

On the other hand, their salary is not sufficient for an adequate standard of living, making the salary issue the most frequent reason for dissatisfaction with the job in NGOs. Another reason is health issues that are most often related to stress.

Based on the results of this study, the following recommendations appear useful. First, the working hours in NGOs in Serbia should be reduced to those defined by work arrangement, specifically because they affect health of women working in NGOs. Second, NGOs should provide training for stress management or coaching for employees that experience high level of stress. This does not seem as impossible to fulfil because NGOs in Serbia provide opportunity for education and because employees assess that the organisation takes good care about them. Finally, NGOs should try to find donations that will help them to expand budget for salaries for employees. This will lead to greater satisfaction of employees.

\section{REFERENCES}

[1] Root Change, www.rootchange.org. Taken from http://www.rootchange.org/our approach/capacity developm ent.shtml, 2018

[2] P. R. Kelly, "An activity theory study of data, knowledge, and power in the design of an international development NGO impact evaluation", Information Systems Journal, vol. 28, 2018, pp. 465-488.

[3] J. Clark, Democratizing development: the role of voluntary organizations. West Hartford, CT: Kumarian Press, 1990.

[4] R. Riddell, and M. Robinson, Non-governmental organizations and rural poverty alleviation. Oxford, UK: Clarendon, 1995.

[5] M. Lindenberg, and J. P. Dobel, "The challenges of globalization for northern international relief and development NGOs", Nonprofit and Voluntary Sector Quarterly, vol. 28, issue 4, 1999, pp. 4-24.

[6] R. Putnam, Making democracy work: civic traditions in modern Italy. Princeton, NJ: Princeton University Press, 1993.

[7] M. Abdelrahman, "NGOs and the dynamics of the Egyptian labour market", Development in Practice, vol. 17, issue 1, 2007, pp. 78-84.
[8] L. D. Brown, and A. Kalegaonkar, "Support organizations and the evolution of the NGO sector", Nonprofit and Voluntary Sector Quarterly, vol. 31, issue 2, 2002, pp. 231258.

[9] R. Tandon, and K. Naidoo, The promise of civil society. In K. Naidoo (Ed.), Civil society at the millennium, West Hartford, CT: Kumarian Press, 1999, pp. 1-16, 1999.

[10] A. Heiss, and J. Kelley, "Between a rock and a hard place: international NGOs and the dual pressures of donors and host governments", Journal of Politics, vol. 79, issue 2, 2017, pp. 732-741, 2017.

[11] M. Kaldor, and I. Vejvoda, Democratization in Central and Eastern Europe. London: Pinter, 1999.

[12] A. Fagan, and M. Ostojic, "The EU and civil society in Serbia: governance rather than politics," Balkanologie, vol. 11 , issue 1-2, 2008.

[13] Ž. Paunović, "Promena u identitetu neprofitnog sektora u Srbiji," Godišnjak Fakulteta političkih nauka, Beograd, vol. 6, issue 7, pp. 55-68, 2012

[14] Građanske inicijative, Public perceptions and attitudes towards NGO sector in Serbia in the year of 2009. http://www.gradjanske.org/wp-content/uploads/2014/11/043Percepcija-i-stavovi-javnosti-o-NVO-sektoru.pdf, accessed 15th Jun 2016, in Serbian, 2009.

[15] Građanske inicijative, NGOs in Serbia. http://www.gradjanske.org/wp-content/uploads/2014/11/044NVO-u-Srbiji-2009.pdf , accessed 15th Jun 2016, in Serbian, 2009.

[16] A. B. Grodeland, "Public perceptions of non-governmental organisations in Serbia, Bosnia \& Herzegovina, and Macedonia," Communist and Post-Communist Studies, vol. 39, 2006, pp. 221-246.

[17] Građanske inicijative, Procena stanja u sektoru organizacija civilnog društva (OCD) u Srbiji. http://civilnodrustvo.gov.rs/upload/old_site/2012/10/Istraziva nje-OCD-Sektor-u-Srbiji-Gradjanske-inicijative-web1.pdf, accessed 15th Jun 2016, in Serbian, 2011.

[18] Euractiv, www.euractiv.org, Taken from https://www.euractiv.com/section/enlargement/news/serbiascivil-sector-ngos-demand-more-rights/, 2019.

[19] H. Metin, and A. Coskun, "The effect of leadership and organizational culture on effectiveness of NGOs: an empirical study", NileJBE, vol. 2, 2016, pp. 3-16.

[20] M. M. Hassan, S. Bashir, and S. M. Abbas, "The impact of project managers' personality on project success in NGOs: the mediating role of transformational leadership", Project Management Journal, vol. 48, issue 2, 2019, pp. 74-87.

[21] V. Padaki, "The human organisation: challenges in NGOs and development programmes", Development in Practice, vol. 17, issue 1,2007 , pp. 65-77.

[22] R. Miković, B. Arsić, Đ. Gligorijević. M. Gačić, D. Petrović, and N. Filipović, "The influence of social capital on knowledge management maturity of nonprofit organizations predictive modelling based on a multilevel analysis", IEEE Access, vol. 7, issue 1, 2019, pp. 47929-47943.

[23] C. Cherniss, Beyond burnout: helping teachers, nurses, therapists and lawyers recover from stress and disillusionment. New York: Routledge, 2016.

[24] M. F. Hatem, "In the shadow of the state: changing definitions of Arab women's "developmental" citizenship rights", Journal of Middle East Women's Studies, vol. 1, issue 3,2005 , pp. 20-45.

[25] J. A. Clark, and W. M. Michuki, "Women and NGO professionalisation: a case study of Jordan", Development in Practice, vol. 19, issue 3, 2009, pp. 329-339 